\title{
PROJECT APPRAISAL TECHNIQUES
}

\author{
Shyam.S.Salim \\ Central Institute of Fisheries Education \\ Mumbai-61
}

\section{Introduction}

There are two types of measures of project appraisal techniques i.e. undiscounted and discounted. The basic underlying difference between these two lies in the consideration of time value of money in the project investment. Undiscounted measures do not take into account the time value of money, while discounted measures do.

Many economic decisions including fish production involve benefits and costs that are expected to occur at future time period. The construction of ponds race ways, and fish tank, for example, requires immediate cash outlay, which with the production and sale of fish, will result in future cash inflows or returns .In order to determine whether the future cash inflows justify present initial investment, we must compare money spent today with the money received in the future.

The time value of money influences many production decisions. Everyone prefers money today to money in the future. Therefore in order to invest a rupee in fish production today, one must be guaranteed a return in the future that is equal to or greater than the rupee invested today. The preference for the rupee now instead of a rupee in the future arises from three basic reasons: Uncertainty, Alternative uses and inflation.

Uncertainty - influences preferences because one is never sure what will take place tomorrow.

Alternative uses - it will determine whether one invests in one project or another.

inflation - affects the purchasing power of the rupee.

Accordingly the undiscounted measures of project worth includes

- Ranking by inspection

- Pay back period

- Proceeds per unit out lay

- Average annual proceeds per unit out lay method

\section{Discounted Measures of project worth}

The technique of discounting permits to determine whether to accept for implementation, projects that have variously shaped time streams i.e., patterns of when costs \& benefits fall during the life of the project that differ from one another - and that are of different durations. The most common means of doing this is to subtract year-by-year the costs from the benefits to arrive at the incremental net benefits stream-the so-called cash flow-and then to discount that. This approach will give one of three discounted cash 
flow measures of project worth:- the net present worth, the internal rate of return or the net benefit investment ratio. Another discounted measure of project worth is to find out the present worth of the cost and benefit stream separately and then to divide the present worth of the benefit stream by the present worth of the cost stream to obtain the benefit-cost ratio.

Because the benefit and cost streams are discounted, the benefit -cost ratio is a discounted measure of project worth. But because the benefit and cost streams are discounted separately rather than subtracted from one another year-by-year, the benefitcost ratio is not a discounted cash flow.

\section{Discounted pay back period}

It is a simple method which estimates the length of the time required for an investment to itself out; that is the number of years required for a firm to cover its original investment from the net cash inflows.

Although the period is easy to calculate, it can lead to erroneous decisions .As can be seen from our example, it ignores income beyond the payback period, \& therefore is biased towards projects with shorter maturity periods. The pay back period is sometimes used by investors who are short of cash and need to reinvest all cash flows that occur in early stages of the projects. Investors who are risk averse often use this technique in evaluating projects. Such investors need to receive cash at the early stages of projects since the future is uncertain. This, the payback period method is somewhat better reflection of liquidity than profitability.

Table: Net cash inflow for project A \& B

Project A

Project B

\begin{tabular}{|l|l|l|l|l|l|l|l|l|l|}
\hline Year & $\begin{array}{l}\text { Invest- } \\
\text { ment }\end{array}$ & $\begin{array}{l}\text { Net } \\
\text { cash } \\
\text { inflow }\end{array}$ & $\begin{array}{l}\text { Discount } \\
\text { factor } \\
(\mathbf{1 2 \% )}\end{array}$ & $\begin{array}{l}\text { Present } \\
\text { value of } \\
\text { Net cash } \\
\text { inflow }\end{array}$ & Year & $\begin{array}{l}\text { Invest- } \\
\text { ment }\end{array}$ & $\begin{array}{l}\text { Net } \\
\text { cash } \\
\text { inflow }\end{array}$ & $\begin{array}{l}\text { Discount } \\
\text { factor } \\
(\mathbf{1 2 \% )}\end{array}$ & $\begin{array}{l}\text { Present } \\
\text { value of } \\
\text { Net cash } \\
\text { inflow }\end{array}$ \\
\hline 0 & 2000 & - & 1.000 & & 0 & 2000 & - & 1.000 & \\
\hline 1 & & 700 & 0.893 & 635.10 & 1 & & 300 & 0.893 & 267.90 \\
\hline 2 & & 600 & 0.797 & 478.20 & 2 & & 400 & 0.797 & 318.80 \\
\hline 3 & & 500 & 0.712 & 356.00 & 3 & & 500 & 0.712 & 356.00 \\
\hline 4 & & 400 & 0.636 & 254.40 & 4 & & 600 & 0.636 & 381.60 \\
\hline 5 & & 300 & 0.567 & 170.10 & 5 & & 700 & 0.567 & 396.90 \\
\hline 6 & & 200 & 0.507 & 101.40 & 6 & & 800 & 0.507 & 405.60 \\
\hline 7 & & 100 & 0.452 & 45.20 & 7 & & 900 & 0.452 & 406.80 \\
\hline
\end{tabular}

The first project (A) is a Rs.2000 investmeht for the purpose of one aerator, \& the second $(B)$ is to invest in a feed shed of equal cost. The payback period for the aerator is 3.5 years and that for feed shed is approximately 4.3 years. If decision- maker wants to cover the cost of investment in the shortest period of time, project $(A)$ will be preferred over (B). But this decision completely unwise because the discounted payback periods for project $(A) \&(B)$ are nearly 6.8 years and 5.8 years respectively. So the project $(B)$ is to be preferred over the other one and this will be actually wise decision. 


\section{Net present value (NPV)}

It is a discounted cash flow technique (DCF). It is the present value discounted at firm's required rate of return on the stream of net cash flows from the project minus the project's net investment. The NPV method uses the discounting formula of a non-uniform or uniform series of payments to value the projected cash flow for each investment alternative at one point in time. To obtain the NPV, following formula is used: -

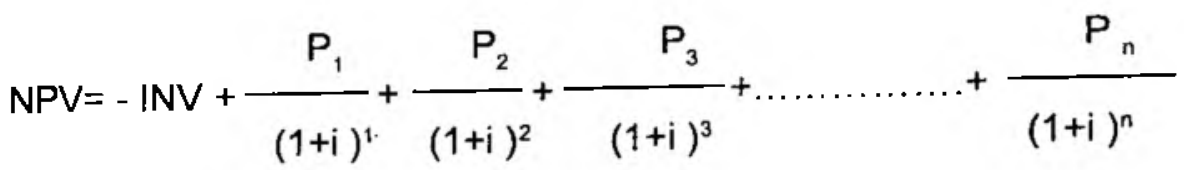

Where, $\mathrm{P} 1 \ldots \ldots \ldots . . . \mathrm{P}_{\mathrm{n}}$ are net cash flows.

$i=$ the interest rate or marginal cost of capital .

$\mathrm{n}=$ the project expected life.

INV = the initial investment.

The model indicates that the net cash flows of the project are discounted and then added to yield the NPV. The initial investment is negative since it represents a cash flow.

or

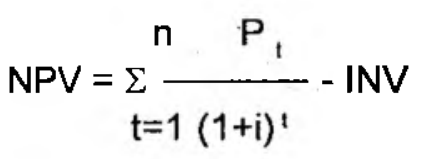

An investment project would be accepted if the NPV $>0$ and rejected if NPV $<0$. This is because the money being invested is greater than the present value of the net cash flow. If $N P V=0$, the decision maker would be indifferent. The NPV method assures that funds may be reinvested at the firm's interest rate. In case of series of cash out flows and cash inflows the can be written as

$N P V=\sum_{t=1}^{n} \frac{B_{1}-C_{t}}{(t+i)^{1}}$

Where,

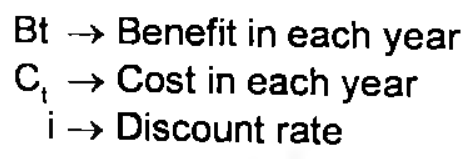




\section{Benefit cost ratio (BCR)}

It is also called as profitability Index (PI). It is the ratio of present value of future net cash flows over the life of the project to the net-investment.

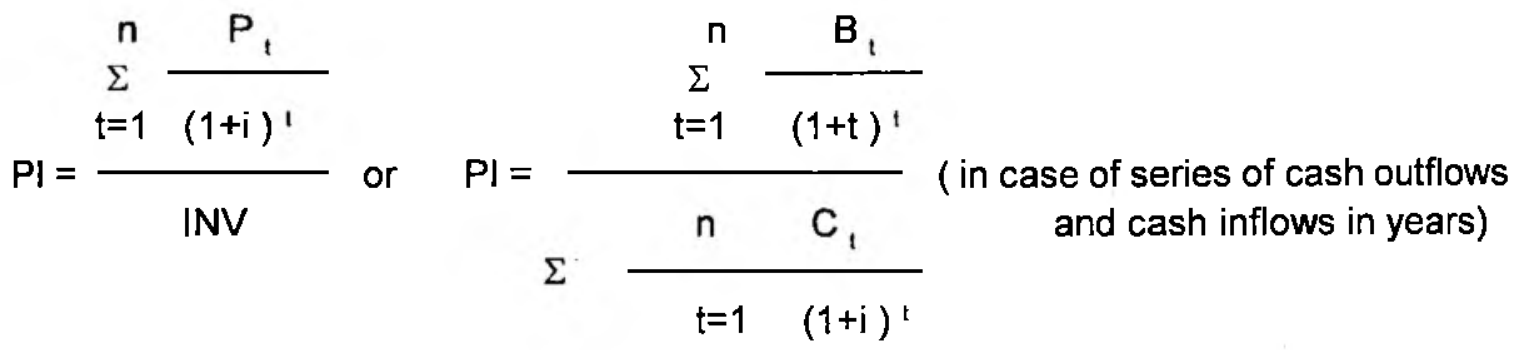

The method usually produces the same result as the NPV and IRR in project evaluation, but it is very important in separating projects of varying sizes. If a project has a PI value greater than or equal to1, $(P I=1)$ it should be accepted and should be rejected if the $\mathrm{PI}$ value is less than $1(\mathrm{PI}<1)$.

Example: A fish culturist has invested and got Net benefit at the end of $1^{\text {st }}, 2^{\text {nd }}, 3^{\text {rd }} \& 4^{\text {th }}$ year of fish culture in the following way:

\begin{tabular}{|l|l|l|l|l|l|}
\hline Year & Investment (Rs.) & Net benefit & $\begin{array}{l}\text { Discount } \\
\text { factor } \\
(12 \%)\end{array}$ & $\begin{array}{l}\text { Present value } \\
\text { investment } \\
-\end{array}$ & $\begin{array}{l}\text { Present value } \\
\text { of Net benefit }\end{array}$ \\
\hline 0 & 40,000 & - & 1.000 & 40,000 & - \\
\hline 1 & 2,000 & 15,000 & 0.893 & 1,786 & 13,395 \\
\hline 2 & 3,000 & 20,000 & 0.797 & 2,391 & 15,940 \\
\hline 3 & 4,000 & 19,000 & 0.712 & 2,848 & 13,528 \\
\hline 4 & 1,000 & 16,000 & 0.636 & 636 & 10,176 \\
\hline Total & 50,000 & 70,000 & & 47,661 & 53,039 \\
\hline
\end{tabular}

NPV = Present value of Net benefit - present value of investment $=53,039-47,661=5378(+)$ ve

BCR or $\mathrm{PI}=\frac{\text { Present value of Net benefit }}{\text { Present value of investment }}=\frac{53,039}{47,661}=1.11$ (more than 1)




\section{Internal Rate of Return (IRR)}

It is the interest rate that will equate the sum of net cash flows to the initial investment. The interest rate that satisfies the equation is called internal Rate of Return (IRR).

There is no way of finding the IRR. One is forced to use a systematic procedure of trial \& error to find out the discount rate that will equate the net cash flows to the initial investment. When the NPV $=0$, then

$$
\begin{aligned}
& \Sigma=\mathrm{P}_{1} \quad{ }^{n} \quad \text { Bt }-\mathrm{cl} \\
& \text { INV or } \Sigma \quad=0 \quad \text { (in case of series of cash flows) } \\
& t=1 \quad(1+i)^{t} \quad t=1 \quad(1+i)^{t} \\
& \mathrm{i}=\text { Internal Rate of Return (IRR) }
\end{aligned}
$$

Acceptability of project depends upon comparing the IRR with the investor's required rate of return (RRR) sometimes called minimum acceptable rate of return (MARR). If IRR is greater than RRR (MARR), accept the project, if IRR is less than that, reject the project, if IRR=RRR, be indifferent.

If NPV is greater than (or less than) zero (0), and only if the IRR is greater than (or less than) RRR, the NPV \& the IRR method result in identical decisions to either accept or reject an independent project

The IRR method implicitly assumes that returns from an investment are reinvested to earn the same rate as the IRR of interest

Example: Initial investment capital for composite fish farming is Rs.25,000.

\begin{tabular}{|l|l|l|l|l|l|}
\hline Year & $\begin{array}{l}\text { Cash flow } \\
\text { (Rs.) }\end{array}$ & $\begin{array}{l}\text { Discount factor } \\
(12 \% \mathrm{Ra})\end{array}$ & $\begin{array}{l}\text { Present value } \\
(12 \%)\end{array}$ & $\begin{array}{l}\text { Discount factor } \\
(20 \% \mathrm{Rb})\end{array}$ & $\begin{array}{l}\text { Present value } \\
(20 \%)\end{array}$ \\
\hline 1 & 12,000 & 0.8929 & 10,715 & 0.8333 & 10,000 \\
\hline 2 & 10.000 & 0.7972 & 7,972 & 0.6944 & 6,944 \\
\hline 3 & 8,000 & 0.7118 & 5,094 & 0.5787 & 4,630 \\
\hline 4 & 6,400 & 0.6356 & 3,432 & 0.4823 & 2,604 \\
\hline \multicolumn{5}{|l}{ Total 27,813} \\
\hline
\end{tabular}

NPV (for 12percent discount rate Ra) $=27,813-25,000=2813$

NPV (for 20percent discount rate $\mathrm{Rb}$ ) $=24,178-25,000=-822$ 


$$
\begin{aligned}
I R R & =R a+\frac{(P v-C) \times A ̈ r}{D P v} \\
& =12+\frac{(27,813-25,000) \times 8}{3635} \\
& =18.19 \text { percent }
\end{aligned}
$$

| Where, $\mathrm{Ra}=$ Minimum rate of interest (i.e.12percent as bank rate of interest) $\mathrm{Pv}=$ Present value of cash flow (at Ra)

C = Capital

$\mathrm{APv}=$ Difference between the present values $=\operatorname{NPV}(\mathrm{Ra})-\mathrm{NPV}(\mathrm{Rb})$

$\mathrm{Ar}=\mathrm{Rb}-\mathrm{Ra}$

The rule for the selection of the project is

$$
\begin{aligned}
& \mathrm{DPBP}=\text { minimum } \\
& \mathrm{NPV}=\text { greater than } 0 \\
& \mathrm{BCR}=\text { more than } 1 \\
& \text { IRR= more than the bank of interest }
\end{aligned}
$$

\section{Risk And Uncertainties In Projects}

One of the real advantages of careful economic and financial analysis in fisheries project is that it may be used to test what happens to the earning capacity of the project if events differ from guesses made about then in planning for e.g. a disease outbreak, fall in prices, natural calamities like floods, etc. These unforeseen incidents can be grouped into two i.e. risks and uncertainties.

\section{Risk}

Few management decisions are made under conditions where the outcomes associated with each possible course of action are known with certainty. Most major managerial decisions are made under conditions of uncertainty. The frequency of uncertainty in managerial decisions and the risk involved dictate risk analysis be given due consideration in farm and project management decisions. Risk refers to the possibility that some unfavorable event will occur. It is the possibility that some unfavorable event will occur. It is the possibility of loss, injury, or exposure to harm. In aquaculture, risk comes from stock losses. Anything, which disrupts the rearing of fish, is likely to jeopardize production and marketing of the final product.

The levels of risk vary among species and at different stages of production. The relative lack of knowledge of fish biology in comparison to some land animals makes fish production more risky than the production of food animals. As Secretan (1988) indicates, on a scale of 1 to 100 , we know 75 percent of the biology of human beings, and perhaps 50 to 60 percent of the biology of chickens, cows, pigs and other farm animals, but only about 20 percent of the biology of aquatic species. There are numerous risks involved in the breeding, hatching and growing of aquatic organisms under intensive management systems.

What sort of risks plagues the aquacultural industry? Risks may be classified into main groups: (1) socio-economic or business risk and (2) physical or pure risks. 


\section{Types of Risk}

\section{Socio-Economic / Business}

Social aspects of socio-economic risks include changes in tastes, attitudes, or social behavior towards production an consumption of a certain species. The expansion of aquaculture depends on individuals changing their attitudes towards species cultured under intensive closed systems. This may be done through government programs, advertising, and public relations. For example, changes in consumer purchases of catfish have been achieved through advertising and public relations. The growing popularity of catfish may be stifled, however, if "off flavour" problems continue to plague the industry.

\section{Economic risks}

Economic risks such as changes in price of inputs and output inflation, recession, depression and other economic conditions which affect national income are primary concerns of commercial fish producers. As demand lags behind supply, producers are concerned that prices will fall. This is presently the case in the U.S. catfish industry. Producers are being warned that they should secure markets before expanding production. Also, the degree of elasticity with respect to supply an demand at both the farm and processor level is a clue to the level of economic risks associated with fish production. Processors facing a more inelastic demand than producers will tend to be less concerned about demand lags. This is one reason that producers are beginning to favor more producer associations or cooperative type marketing organizations.

\section{Marketing risks}

Risks may also result from uncertainty in demand, supply and prices. When to move the product to market is the age-old nemesis of farmers. Fish farmers are no different. Significant seasonal price level differences exist in many aquaculture product markets. Today, more farmers in colder climate are over wintering fish to try to market them when thee is less supply available to consumers. Additionally, new technologies and product forms are being evaluated in an attempt to avoid some of the marketing risks. Smoked fish as well as dried, frozen, or canned fish are forms used in various markets to reduce the risks associated with marketing time.

Assume that forecasters are overly optimistic in their estimates of prices and consumer demand. This optimism is likely to encourage farmers to intensify production (higher stocking rates) in the short-run and expand production (more ponds) in the long run. Intensification increases the potential for diseases, problems such as "off-flavor", and other environmental concerns. The fish arrive at the market only to remain unsold because of weak consumer demand resulting from a dislike for the quality of the fish on the shelf, or insufficient income to purchase fish and other market foods. 
Longer-term expansion of production means greater amounts of capital and land committed to the aquacultural practice. Because ponds are much easier to build than to remove, these commitments tend to become irreversible, even if prices decline. Once again market conditions dictate difficulties for the producer.

\section{Production risks}

Many of the marketing risks are also related to production problems. Marketing problems may be logistical in nature, which may impede production schedules. The timely supply of fingerlings may affect the quantity of food fish produced at a given time. This may result in grave financial problems for producers. Production risks may also be due to lack of trained manpower to manage the operation. This results in serious constraint or even failure in any aquacultural enterprise.

\section{Other risks}

Other socio-economic risks encountered are financial and political. Financial risks relate to changes in supply of funds for production and marketing. Credit restriction and availability often affect the aquacultural industry. Lack of education and understanding of aquacultural production processes among lenders is common in areas where the industry is developing.

Political risks affect not only an enterprise, but the whole sector. Changes in government and governmental policies have been known to cause changes in supply and demand of inputs and fish. Governmental regulations may affect all stages and aspects of the industry. Regulations on feed, import of inputs, the introduction of species, and changes in labour laws may greatly influence the industry.

\section{Physical or pure risks}

Physical risks results from conditions of nature, such as rain windstorms, clouds, flooding, and drought. Other types of pure risks are plant breakdowns, and failure of safety and other devices. These risks associated with physical or pure risks can be managed to minimize their effects on producers.

\section{Uncertainty}

It is a situation in which the probability of an outcome is not known. Insurance cannot provide any cover against uncertainty. Uncertainty is a state of being doubtful about future events, which cannot be foreseen exactly.

\section{Types of Uncertainty :}

- Price uncertainty: It is associated with the price of products and input factors, such as price of fish in a market.

- Yield uncertainty: The fluctuations in yield are associated with weather conditions and incidence of diseases and pests and the impact of new practices. 
- Technological uncertainty: Technological changes influence production function and create conditions of variability, which, in turn, lead to uncertainty.

- Institutional uncertainty: Conditions of tenure, functioning of credit agencies, action and outlook of farmers are examples of institutional uncertainty.

Normally risks and uncertainties are removed by the following methods:

(a) Diversification

(b) Crop insurance

(c) Continuous or Sequential Marketing

(d) Future Market or Production Contracts

(e) Government Programs

(f) Third-Party Equity Capital

(g) Use of Safety Device

The risk anc uncertainties in the fisheries projects can be accounted by the following methods

\section{- Sensitivity analysis}

Sensitivity analysis is a simple technique to assess the effects of adverse changes on a project. It involves changing the value of one or more selected variable and calculating the resulting change in NPV or IRR. The extent of change in the selected variable to test can be derived from post evaluation and other studies of similar projects. Changes in variables can be assessed one at a time to identify the key variables. Possible combinations can also be assessed. . Sensitivity analysis answers questions like what happens to NPV if the sales of the output are 10 tons rather than the expected 15 tons? What will happen to NPV if the economic life of the project is only 6 yrs rather than the expected 8 years? How sensitive is the projects financial and economic rate of return or net benefit investment ratio to increased construction costs etc.

Where the project is shown to be sensitive to the value of a variable that is uncertain, mitigating actions should be considered. This can include project level actions, such as long-term supply contracts or pilot phases; sector level actins, such as price changes or technical assistance programs; or national level actions, such as changes in tax and incentive policies, where there is exceptional uncertainty, the project may have to be redesigned or implemented first on pilot basis.

Sensitivity and risk analysis can be used to assess the effects of changes in project variables that are quantifled. The results can be presented together with recommendations on what actions to take or which variables to monitor during implementation and operation. However, many projects involve institutional and social risks that cannot be readily quantified. A statement of such risks and any mitigating actions should be included alongside the conclusions from sensitivity and risk analysis. 


\section{Merits of sensitivity analysis}

1. It forces management to identify the underlying variables and their relationships.

2. It shows how robust or vulnerable a project is to change in underlying variables.

3. It indicates the need for further work in terms of gathering information if NPV or IRR is highly sensitive to changes in some variable

Generally projects are sensitive to change in 4 principal areas. These and the technique of sensitivity analysis are considered below:

\section{- Uncertainties of Price Receivables}

Probably every aquacultural project should be examined to see what happens if the assumptions about the sale price of the project's product prove wrong. For this the analyst can make alternative assumptions about future prices and see how these affect the net present worth the financial and economic rates of return, or the net benefit-investment ratio (often abbreviated as $\mathrm{N} / \mathrm{K}$ ratio).

\section{- Delay in implementation}

Delay in implementation affects most aquacultural projects. Farmers may fail to adopt new practices as rapidly an anticipated or they may find it harder to master new techniques than was thought. Other technical difficulties may be underestimated. There may be delays in ordering and receiving new equipment. Unavoidable administrative problems and requirements may delay the project. Testing to determine the effects of delay on the net present worth, the financial and economic rates of return and the net benefit investment ratio of a proposed agricultural investment is an important part of the sensitivity analysis.

\section{- Cost overrun}

Almost every aquacultural project should be tested for sensitivity to cost overrun. Projects tend to be very sensitive to cost overrun especially for construction because so often the costs are incurred early in the project when they weigh heavily in the discounting process and are for facilities that must be complete before any benefit can be realized. $A$ project that has a quite attractive return if the estimated cost is in fact realized may be only marginally acceptable or unacceptable if costs early in the implementation phase rise significantly.

Cost estimates often are not very firm is one more reason why projects should be tested for cost overrun.

A test that shows a project to be very sensitive to cost overrun may signal to those who must make investment decisions that it is important to have firms cost estimates before proceeding with the final decision, even if obtaining firm estimates may mean a delay in the start of project implementation. If a project manger and those to whom he reports that it is important to contain costs if the project is to make its expected contribution to increasing national income. 
- Yield

The analyst may wish to test a proposed project for its sensitivity to errors in estimated yield. There is a tendency in projects to be optimistic about potential yields, especially when a new cropping pattern is being proposed and the agronomic information is based mainly on experimental trials. A test to determine how sensitive the projects net present worth, financial and economic rates of return, or net benefit-investment ratio are to lower yields not only may provide information useful in deciding whether to implement the project, but also may emphasize the need to ensure sufficient extension services if the project is to be as high-yielding as could reasonably be experienced.

Sensitivity analysis is a straightforward (but often quite sufficient) means of analyzing the effects of risk and uncertainty in project analysis. A much more elaborate technique of risk analysis using probability [Pouliquen (1970) approach] is generally called "probability analysis". In contrast, the techniques we have been discussing (including sensitivity analysis) are usually called "most probable outcome analysis".

\section{Problem :}

For the following fisheries project perform the sensitivity analysis for the three different cases of

(i) Increasing cost of capital.

(ii) Increased cost of project due to risks involved at 10 and 20 percent cost like.

(iii) Uncertainties due to the differences in the price receivables at 10,20 and 30 percent reduction for the yield.

\section{Sensitivity analysis}

Case I: Increasing Cost of Capitals

\begin{tabular}{|l|l|l|l|l|l|l|l|l|l|l|l|}
\hline Y & Cost & Benefit & D.F. & D.C. & D.B. & D.F. & D.C. & D.B. \\
a & & & $12 \%$ & $12 \%$ & $20 \%$ & $20 \%$ & $20 \%$ & $25 \%$ & $\begin{array}{l}\text { D.F. } \\
25 \%\end{array}$ & $\begin{array}{l}\text { DB. } \\
25 \%\end{array}$ \\
\hline r & 25000 & 0 & 1 & 25000 & 0 & 1 & 25000 & 0 & 1 & 25000 & 0 \\
\hline \hline & 5000 & 20000 & 0.893 & 4465 & 17860 & 0.833 & 4165 & 16660 & 0.8 & 4000 & 16000 \\
\hline 3 & 5000 & 20000 & 0.797 & 3985 & 15940 & 0.694 & 3470 & 13880 & 0.64 & 3200 & 12800 \\
\hline \hline & 5000 & 20000 & 0.712 & 3560 & 14240 & 0.579 & 2895 & 11580 & 0.512 & 2560 & 10240 \\
\hline 5 & 5000 & 20000 & 0.636 & 3180 & 12720 & 0.482 & 2410 & 9640 & 0.41 & 2050 & 8200 \\
\hline 5 & 5000 & 25000 & 0.567 & 2835 & 14175 & 0.402 & 2010 & 10050 & 0.328 & 1640 & 8200 \\
\hline & & & & 43025 & 74935 & & 39950 & 61810 & & 38450 & 55440 \\
\hline & & & & NPV & 31910 & & NPV & 21860 & & NPV & 16990 \\
\hline & & & & BCR & 1714 & & BCR & 1.5471 & & BCR & 1.4418 \\
\hline
\end{tabular}




\section{Inference}

The computation of the NPV and BCR at different cost of capital indicates that the project is feasible and profitable even at 25 percent discount rate. At 25 percentages discount rate also there exists a positive NPV and BCR of more than one. The exercise indicates the high yielding capacity of the project even at higher discount rates.

\section{Case II: Escalation of the cost of the project due to the different risks involved}

\begin{tabular}{|l|l|l|l|l|l|l|l|l|l|l|l|}
\hline Y & Cost & Benefit & $\begin{array}{l}\text { D.B. } \\
\text { a }\end{array}$ & D.C. & $\begin{array}{l}\text { D.B. } \\
12 \%\end{array}$ & $\begin{array}{l}\text { Cost } \\
\text { increase } \\
\text { by } 10 \%\end{array}$ & $\begin{array}{l}\text { D.C. } \\
12 \%\end{array}$ & $\begin{array}{l}\text { D.B. } \\
12 \%\end{array}$ & $\begin{array}{l}\text { Cost } \\
\text { increase } \\
\text { by } 20 \%\end{array}$ & $\begin{array}{l}\text { D.C. } \\
12 \%\end{array}$ & $\begin{array}{l}\text { DB. } \\
12 \%\end{array}$ \\
\hline 1 & 25000 & 0 & 1 & 25000 & 0 & 27500 & 27500 & 0 & 30000 & 30000 & 27500 \\
\hline 2 & 5000 & 20000 & 0.893 & 4465 & 17860 & 5500 & 4911.5 & 17860 & 6000 & 5358 & 4911.5 \\
\hline 3 & 5000 & 20000 & 0.797 & 3985 & 15940 & 5500 & 4383.5 & 15940 & 6000 & 4782 & 4383.5 \\
\hline 4 & 5000 & 20000 & 0.712 & 3560 & 14240 & 5500 & 3916 & 14240 & 6000 & 4272 & 3916 \\
\hline 5 & 5000 & 20000 & 0.636 & 3180 & 12720 & 5500 & 3498 & 12720 & 6000 & 3816 & 3498 \\
\hline 6 & 5000 & 25000 & 0.567 & 2835 & 14175 & 5500 & 3118.50 & 14175 & 6000 & 3402 & 3118.5 \\
\hline & & & & 43025 & 74935 & 5500 & 47327.5 & 74935 & 60000 & 51630 & 47327.5 \\
\hline & & & & NPV & 31910 & & NPV & 27607.5 & & NPV & -4302.5 \\
\hline & & & & BCR & 1.71 & & BCR & 1.58 & & BCR & 0.92 \\
\hline
\end{tabular}

\section{Inference}

On increasing the cost of the project taking into consideration the different risks involved the computed NPV and the BCR values indicate that the project is feasible and economical unto a discount level rate of less than 20 percent cost increase. At 20 percent increase in the total cost of the project the NPV appears to be negative and the BCR is lesser than one, which are negative indicators of project appraisal.

\section{CASE III: Uncertainties resulting due to the differences in the price receivables}

\begin{tabular}{|l|l|l|l|l|l|l|l|l|l|l|l|}
\hline Y & Cost & Benefit & $\begin{array}{l}\text { D.F. } \\
12 \%\end{array}$ & $\begin{array}{l}\text { D.C. } \\
12 \%\end{array}$ & $\begin{array}{l}\text { D.B. } \\
12 \%\end{array}$ & $\begin{array}{l}\text { Reduc- } \\
\text { tion in } \\
\text { benefit } \\
\text { of } 10 \%\end{array}$ & $\begin{array}{l}\text { Dis- } \\
\text { counted } \\
\text { benefit }\end{array}$ & $\begin{array}{l}\text { Reduc- } \\
\text { tion in } \\
\text { benefit } \\
\text { of } 20 \%\end{array}$ & $\begin{array}{l}\text { Dis- } \\
\text { counted } \\
\text { benefit }\end{array}$ & $\begin{array}{l}\text { Reduc- } \\
\text { tion in } \\
\text { benefit } \\
30 \%\end{array}$ & $\begin{array}{l}\text { Dis- } \\
\text { counted } \\
\text { benefit }\end{array}$ \\
\hline 1 & 25000 & 0 & 1 & 25000 & 0 & 0 & 0 & 0 & 0 & 0 & 0 \\
\hline 2 & 5000 & 20000 & 0.893 & 4465 & 17860 & 18000 & 16074 & 16000 & 14288 & 14000 & 12502 \\
\hline 3 & 5000 & 20000 & 0.797 & 3985 & 15940 & 18000 & 14346 & 16000 & 12752 & 14000 & 11158 \\
\hline 4 & 5000 & 20000 & 0.712 & 3560 & 14240 & 18000 & 12816 & 16000 & 19392 & 140000 & 9968 \\
\hline 5 & 5000 & 20000 & 0.636 & 3180 & 12720 & 18000 & 11448 & 16000 & 10176 & 14000 & 8904 \\
\hline 6 & 5000 & 25000 & 0.567 & 2835 & 14175 & 22500 & 12757.5 & 20000 & 11340 & 17500 & 9922.5 \\
\hline & & & & 43025 & 74935 & & 671441.5 & 84000 & 59948 & 73500 & 52454.5 \\
\hline & & & & NPV & 31910 & NPV & 24416.5 & NPV U & 16923 & NPV & 9429.5 \\
\hline & & & & BCR & 1.71 & BCR & 1.56 & BCR & 1.39 & BCR & 1.21 \\
\hline
\end{tabular}




\section{Inference}

The uncertainties in the project benefit stream can be sensitized by the ex-ante approach of reducing the anticipated project benefit stream at 10,20,30 percentages. The computed NPV and BCR ratios indicate that the project can withstand uncertainties to the tune of even 30 percent reduction in the yield due to the different uncertainties. The NPV and $\mathrm{BCR}$ at 30 percentage reduction in the yield in the project benefit stream was found to be Rs 9429 and1.21 respectively

\section{Limitations of sensitivity analysis}

1. It may fail to provide leads if sensitivity analysis merely presents complicated set of switching values it may not shed light on the characteristics of the project.

2. The study of the impact of variation in one factor at a time, holds, other factors constant, may not be very meaningful when underlying factors are likely to be interrelated. 